\title{
46. NEOGENE CIRCULATION IN THE SOUTHERN INDIAN OCEAN: EVIDENCE FROM BENTHIC FORAMINIFERS, CARBONATE DATA, AND STABLE ISOTOPE ANALYSES (SITE 751) ${ }^{1}$
}

\author{
A. Mackensen, ${ }^{2}$ E. Barrera, ${ }^{3}$ and H.-W. Hubberten ${ }^{2}$
}

\begin{abstract}
Lower Miocene through upper Pleistocene benthic foraminifer assemblage records from Ocean Drilling Program Site 751 on the Southern Kerguelen Plateau $\left(57^{\circ} 44^{\prime} \mathrm{S}\right.$, water depth $\left.1634 \mathrm{~m}\right)$ were combined with benthic and planktonic foraminifer oxygen and carbon isotope records and high-resolution $\mathrm{CaCO}_{3}$ data from the same site. Implications for the Neogene productivity and paleoceanography of the southern Indian Ocean are discussed. We used distinctive features of the Miocene $\delta^{18} \mathrm{O}$ and $\delta^{13} \mathrm{C}$ curves for stratigraphic correlation.

Coinciding with a lower middle Miocene hiatus from 14.2 to $13.4 \mathrm{Ma}$, there was a rapid increase in benthic $\delta^{18} \mathrm{O}$ values by $1.2 \%$. This distinct increase occurs in middle Miocene benthic foraminifer oxygen isotope curves from all oceans. No major change, however, in benthic foraminifer faunal composition occurred in this period of growth of the Antarctic ice cap and cooling of deep ocean waters (14.9-14.2 Ma).

A drastic change in benthic foraminifer faunas coincided with a hiatus from 8.4 to $5.9 \mathrm{Ma}$. Shortly after this hiatus, in the latest Miocene, the $\mathrm{CaCO}_{3}$ content of the sediments dropped from $75 \%$ to $0 \%$. From that time $(\approx 5.8$ Ma) through the early Pliocene, Site 751 has been situated beneath a high biogenic siliceous productivity zone.

Carbonate contents of upper Pliocene and Pleistocene sediments vary between $20 \%$ and $70 \%$. The benthic foraminifer faunas in the uppermost Pliocene and lower Pleistocene reflect strong bottom current conditions, in contrast to those in the upper Pleistocene, which indicate calm sedimentation and high food supply. High $\delta^{13} \mathrm{C}$ values of planktonic foraminifers compared with low values of benthic foraminifers suggest high primary productivity in the late Pleistocene. The changes in productivity were probably a result of latitudinal migration and meandering of the Polar Frontal Zone.
\end{abstract}

\section{INTRODUCTION}

Drilling during Leg 120 at Site $751\left(57^{\circ} 43.6^{\prime} \mathrm{S}, 79^{\circ} 48.9^{\prime} \mathrm{E}\right.$, water depth $1634 \mathrm{~m}$ below sea level [mbsl]) recovered a thick sequence of mixed biosiliceous and calcareous ooze of late Pleistocene through middle early Miocene age. Site 751, located close to the present Polar Frontal Zone, yielded a Miocene section with a high sedimentation rate of 15-20 $\mathrm{m} / \mathrm{m} . \mathrm{y}$. Thus, the site is sensitive to past changes in the position and strength of this climate-indicative hydrographic feature. Indeed, the unique opportunity for detailed biostratigraphic analyses on both calcareous (Berggren, this volume) and siliceous (Harwood and Maruyama, this volume; Lazarus, this volume) microfossils, in combination with stable isotope records can make this site important for southern high-latitude middle and upper Miocene stratigraphy.

In the Neogene sections of Sites 747, 748, and 751, drilled during Leg 120 on a north-south transect across the Kerguelen Plateau, differences in benthic foraminifer faunal composition and in the timing of faunal changes occurred (Mackensen, this volume). Paleoenvironmental interpretations derived from comparison with Holocene benthic foraminifer assemblages are rarely unequivocal, even in local, geographically limited, paleoenvironmental reconstructions. In this paper, we present a detailed carbonate record and stable isotope records of benthic and planktonic foraminifers from Site 751 to add to environmental reconstructions based on benthic foraminifer faunal data.

\footnotetext{
${ }^{1}$ Wise, S. W., Jr., Schlich, R., et al., 1992. Proc. ODP, Sci. Results, 120: College Station, TX (Ocean Drilling Program).

2 Alfred Wegener Institute for Polar and Marine Research, P. O. Box 120161, D-2850 Bremerhaven, Federal Republic of Germany.

${ }^{3}$ Department of Geological Sciences, University of Michigan, 1006 C. C. Little Bldg., Ann Arbor, MI 48109-1063, U.S.A.
}

During the Miocene major phases of growth and decay of Antarctic ice caps occurred. The Drake Passage widened and deepened, the Iceland-Greenland-Faeroe ridge further subsided, and the Tethys closed (Kennett, 1982, 1985). Periods of particular interest are the early middle Miocene, when the growth of a major continental ice sheet on East Antarctica intensified (Savin et al., 1975; Shackleton and Kennett, 1975; Barker, Kennett, et al.; 1988; Hambrey et al., 1989), and the late Miocene, when major ice shelves in the Weddell and Ross seas and in Prydz Bay built up (Ciesielski et al., 1982; Mercer, 1983; Barrett, 1989; Hambrey et al., 1991), and when the thermal structure of the oceans and the circulation of deep and intermediate water masses began to assume the characteristics of the modern oceans (Douglas and Savin, 1975; Woodruff and Savin, 1989).

\section{OCEANOGRAPHIC SETTINGS}

The Antarctic Circumpolar Current (ACC), driven eastward round Antarctica by prevailing westerly winds, is the dominant feature of today's Antarctic Ocean circulation. The volume transport capacity of the ACC is estimated to be 130 Sv (1 Sverdrup $[\mathrm{Sv}]=10^{6} \mathrm{~m}^{3} / \mathrm{s}$ ) with an average velocity of $25-30 \mathrm{~cm} / \mathrm{s}$ at the surface and about $10 \mathrm{~cm} / \mathrm{s}$ at $3000 \mathrm{~m}$ water depth (Whitworth, 1988).

The Polar Front is the southern boundary of the Polar Frontal Zone, a transition zone where cold, less saline Antarctic surface water meets warmer, more saline subantarctic surface water. The northern boundary of the Polar Frontal Zone is called the Subantarctic Front. The Polar Front is on average situated at about $52^{\circ}-53^{\circ} \mathrm{S}$ (Hellmer and Bersch, 1985). The position of the Polar Frontal Zone is important. The strong thermal gradients and the upwelling of deeper northern waters associated with the Polar Frontal Zone act as a faunal barrier for planktonic organisms and form an area of high primary productivity. 
At the Kerguelen Plateau, however, between Kerguelen and Heard Islands, the positions of the major oceanographic boundaries are presently highly variable, and it is still uncertain whether there exists a Subantarctic Zone at all (Whitworth, 1988; Deacon, 1983). There are differences in the rate of productivity between the western and eastern sides of the Kerguelen Plateau, attributed to upwelling on the eastern side (Plancke, 1977).

In the southern Indian Ocean, the Circumpolar Deep Water (CDW) is a mixture of deep and bottom waters from other regions; as such, it accounts for two-thirds of the water masses driven by the ACC (Emery and Meincke, 1986). The CDW is composed of $45 \%$ Weddell Sea water, $30 \%$ Pacific and Indian ocean intermediate waters, and $25 \%$ deep water originating from the North Atlantic (Broecker et al., 1985). On the Central Kerguelen Plateau, the CDW bathes the Leg 120 sites presently.

The deepest of the water masses affected by the ACC is the Antarctic Bottom Water (AABW), which is mainly formed in the Weddell and Ross seas. The formation of AABW is linked either to large floating ice shelves, such as the Ronne and Ross ice shelves and the super-cooling beneath them (Foldvik et al., 1985; Foldvik and Gammelsrød, 1988), or to polynyas kept open in front of the ice-shelf edges by katabatic winds, or to a combination of both. The bathyal and abyssal water masses (CDW and AABW) around the Kerguelen Plateau today originated for more than $50 \%$ in the Weddell Sea.

\section{METHODS}

\section{Samples and Measurements}

Five $20-\mathrm{cm}^{3}$ samples from each section of Hole 751A down to Core $120-751 \mathrm{~A}-13 \mathrm{H}$ in the uppermost lower Miocene (118.7 $\mathrm{m}$ below seafloor [mbsf]) and two samples per section from Cores $120-751 \mathrm{~A}-14 \mathrm{H}$ through $-18 \mathrm{H}$ were taken. The samples were washed through a $63-\mu \mathrm{m}$ mesh sieve and dried in an oven at $60^{\circ} \mathrm{C}$. The carbonate content was determined with a Coulomat 702, which measures the $\mathrm{CO}_{2}$ released from carbonate by treatment with $14 \%$ phosphoric acid (Table 1 , on microfiche in back pocket).

Stable isotope measurements were carried out using a Finnegan MAT 251 mass spectrometer and an automatic carbonate preparation device. Standard deviations of measurements are $<0.04 \%$ and $<0.06 \%$ for carbon and oxygen, respectively. Data are related to the VPDB standard through repeated analyses of National Bureau of Standard isotopic reference material 19 (Hut, 1987). The benthic signal was measured on Trifarina angulosa and Cibicidoides spp. from the Pleistocene, on Cibicidoides spp. from the Pliocene and upper Miocene, and on Nuttallides umbonifer and Cibicidoides spp. from the middle and lower Miocene. About $90 \%$ of the data was measured on the epibenthic Cibicidoides spp. (Table 2, on microfiche in back pocket). Whenever possible, specimens from the $>250-\mu \mathrm{m}$ size fraction were picked and analyzed.

Stable oxygen and carbon isotopic values of Trifarina angulos $a$ and $N$. umbonifer were adjusted to Cibicidoides by constant values of $-0.67 \%$ or for $\delta^{18} \mathrm{O}\left(0.33 \%\right.$ for $\left.\delta^{13} \mathrm{C}\right)$, and $0.20 \%$ for $\delta^{18} \mathrm{O}\left(0.49 \%\right.$ for $\left.\delta^{13} \mathrm{C}\right)$, respectively (Figs. 1-3). These values were derived by analyzing samples in which species ranges overlap (Table 2 , microfiche). Plots of the benthic $\delta^{18} \mathrm{O}$ values (Figs. 1 and 3 ) were adjusted by $0.69 \%$ to account for isotopic disequilibrium (Savin et al., 1981). For ease in evaluating the significance of variation within the data, a weighted 11-point running average was used (Fig. 3). Because only three specimens were used for one isotopic analysis, we often analyzed replicate samples. Results obtained by measuring several sets of specimens from the same sample were arithmetically averaged before being added to the main plots.

The planktonic signal was measured on Neogloboquadrina pachyderma (Pliocene-Pleistocene) and Globigerina bulloides, G. falconensis, G. woodi, Globigerina spp., and Globorotalia scitula (Miocene) from the $>125-\mu \mathrm{m}$ size fraction. In addition to a raw data plot, a smoothed curve calculated by means of a weighted 11-point running average is also given for the planktonic data (Fig. 4). Apart from $N$. pachyderma and $G$. scitula, we used spinose, symbiontbearing globigerinids that are supposed to record the isotopic composition of the near-surface waters (Savin and Douglas, 1973; Barrera et al., 1985). Globorotalia scitula lives at various depths during an annual cycle (Hemleben et al., 1989); and Neogloboquadrina pachyderma is found in water as much as $200 \mathrm{~m}$ below the surface; it precipitates its test in equilibrium with dissolved oxygen of the surface-water masses and in slight disequilibrium with dissolved carbon (Labeyrie et al., 1986; Johannessen, 1987).

For benthic foraminifer analyses, the residues of two or three samples per section were dry sieved over $125-\mu \mathrm{m}$ and aliquots from this fraction were analyzed. A minimum of 300 specimens was picked and counted when possible (raw data, range, and taxonomy of species in Mackensen, this volume). We used orthogonal, rotated Q-mode principal component analysis on Site 751 data only, and reduced the benthic foraminifer raw data matrix from 104 species $\times 87$ samples to six principal components (PCs) that explained $80.1 \%$ of the total variance. The results and the interpretation of this analysis are very similar (as expected) to the results of an analysis of a larger, combined data set of Sites 747, 748, and 751 (Mackensen, this volume). Therefore, for discussion of the Site 751 faunas, in this paper we used benthic foraminifer assemblages and assemblage boundaries, as defined from the large, combined data set. For a detailed faunal description as well as the PC scores and loadings, we refer to Mackensen (this volume).

\section{Stratigraphy and Age Model}

The age model used in this paper is preliminary and is based on the biostratigraphic and paleomagnetic data outlined by the Shipboard Scientific Party (Schlich, Wise, et al., 1989) and Heider et al. (this volume). Modifications based on the reinterpretation of the lower middle Miocene parts of the paleomagnetic record (i.e., downcore shift of anomaly correlative $5 \mathrm{~B}$ ) as proposed by Berggren (this volume) are included. In addition, we adopted the age model outlined by Harwood and Maruyama (this volume) for the upper Miocene and the Miocene/Pliocene boundary.

At this stage of investigation, different age models are used by different biostratigraphic workers for interpreting Site 751 material. We preliminarily correlated distinct characteristic features of the benthic stable isotope curves, measured in this paper, with Miocene stable isotope stratigraphies proposed by Miller et al. (1991), Wright and Miller (this volume), and Woodruff and Savin (in press) to give additional stratigraphic data points (Table 3 and Fig. 5). Then, on the basis of this age model, we interpreted and discussed the benthic foraminifer, carbonate, and stable isotope data. The time scale of Berggren et al. (1985) was used throughout.

The sedimentary sequence of Hole $751 \mathrm{~A}$ is interrupted by at least three major unconformities. One in the lower middle Miocene (14.2-13.4 Ma), dated by means of stable isotope stratigraphy (this paper), another one in the upper Miocene close to the Miocene/Pliocene boundary (8.4-5.9 Ma) dated by diatom stratigraphy (Harwood and Maruyama, this vol- 


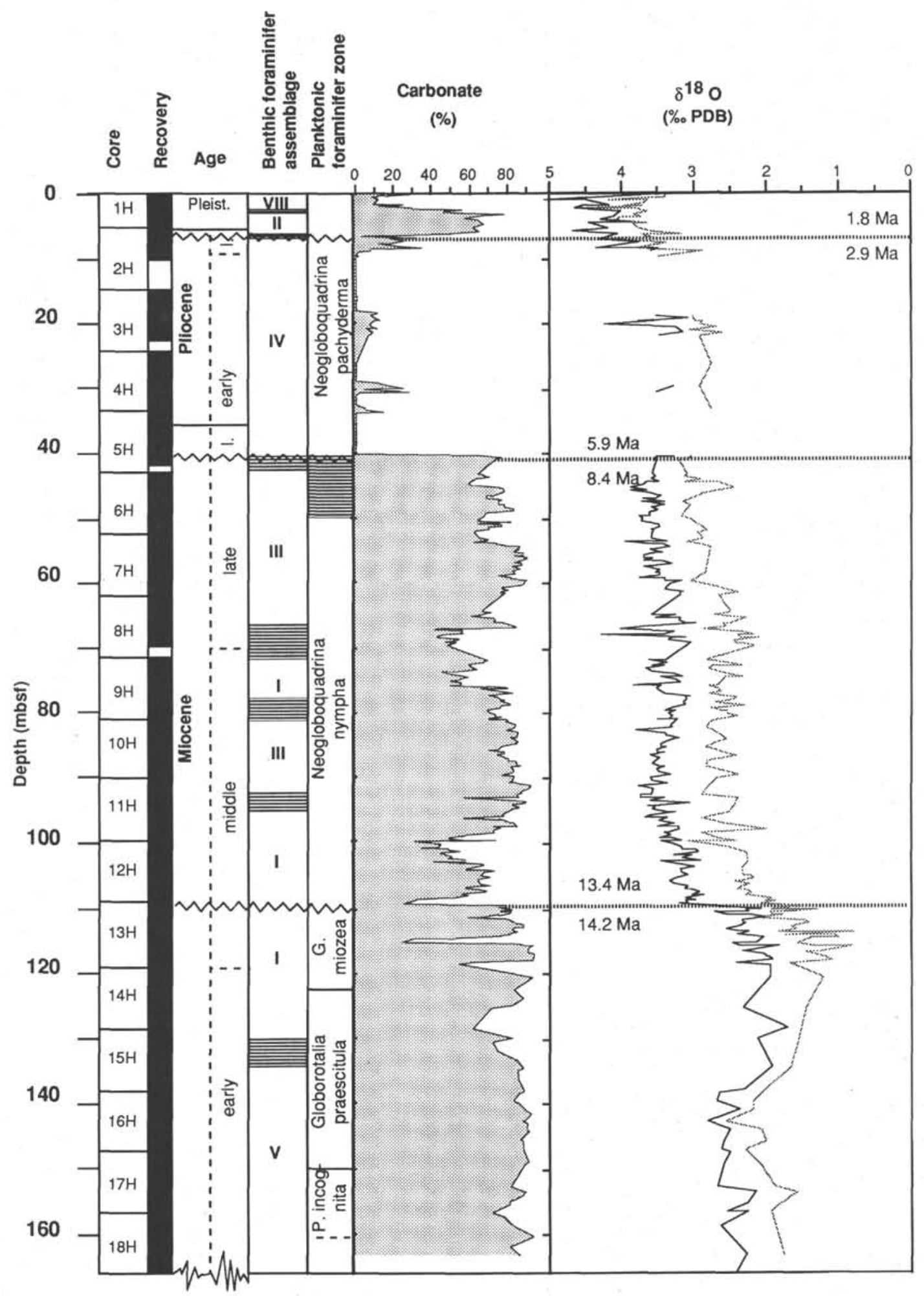

Figure 1. Oxygen isotope data of benthic (full line) and planktonic (dotted line) foraminifers are plotted vs. sub-bottom depth (mbsf). The benthic curve is given adjusted to Cibicidoides spp., and by $0.69 \%$ to account for isotopic disequilibrium. Age determinations are according to the Shipboard Scientific Party (Schlich, Wise, et al., 1989) with modifications by Harwood and Maruyama (this volume), Berggren (this volume), Heider et al. (this volume), and this paper (see discussion in "Stratigraphy and Age Model" section). For comparison the $\mathrm{CaCO}_{3}$ content of the bulk sediment, the benthic foraminifer assemblages (Mackensen, this volume), and planktonic foraminifer zones (Berggren, this volume) are given on the left-hand side of the figure. The multiple lines between benthic foraminifer assemblages and planktonic foraminifer zones give the uncertainty interval of boundaries caused by sampling density and poor preservation, respectively. 


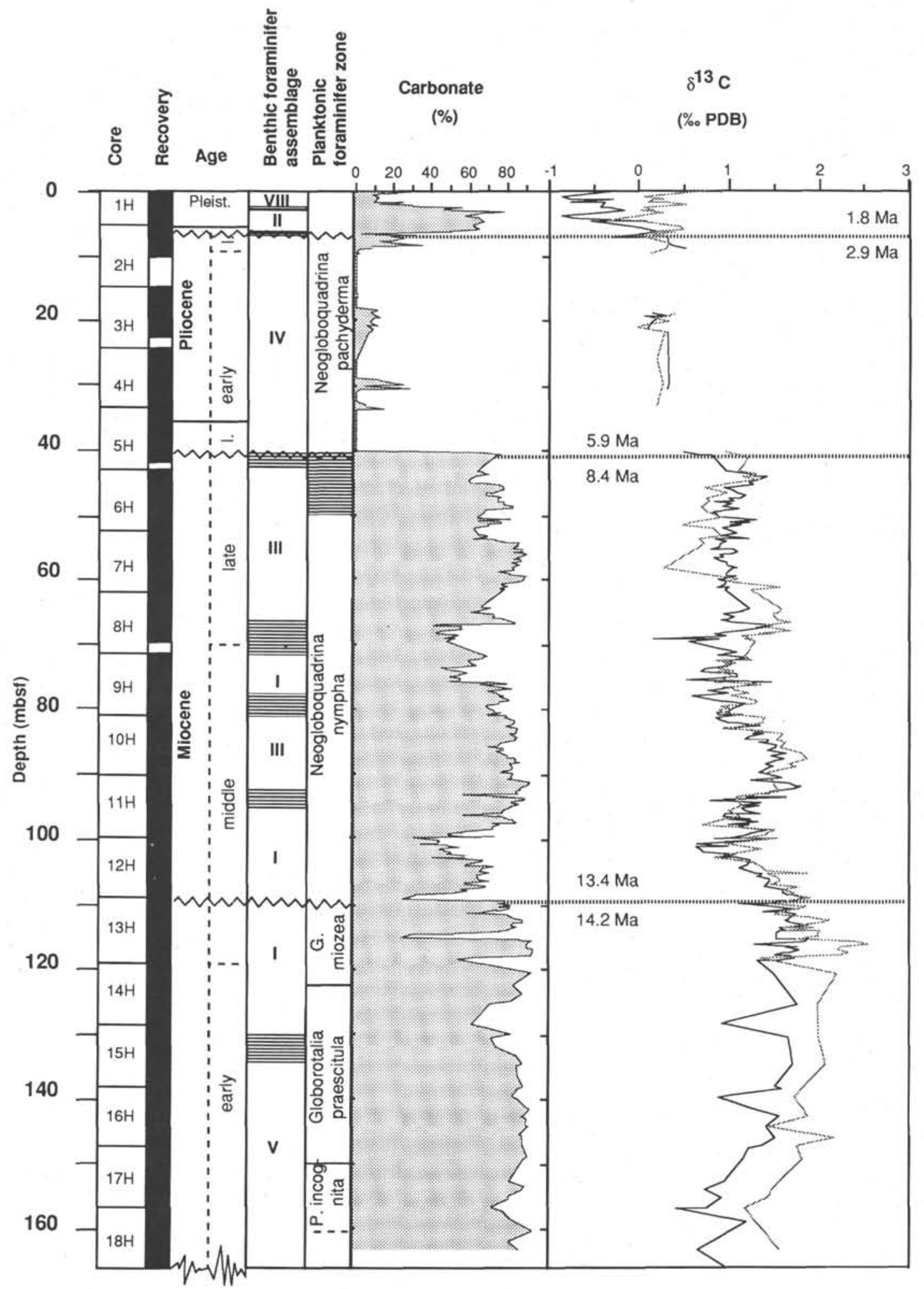

Figure 2. Carbon isotope data of benthic (full line) and planktonic (dotted line) foraminifers are plotted vs. sub-bottom depth (mbsf). The benthic curve is given adjusted to Cibicidoides spp. Age determinations are according to the Shipboard Scientific Party (Schlich, Wise, et al., 1989) with modifications by Harwood and Maruyama (this volume), Berggren (this volume), Heider et al. (this volume), and this paper (see discussion in "Stratigraphy and Age Model" section). For comparison, the $\mathrm{CaCO}_{3}$ content of the bulk sediment, the benthic foraminifer assemblages (Mackensen, this volume), and planktonic foraminifer zones (Berggren, this volume) are given on the left-hand side of the figure. The multiple lines between benthic foraminifer assemblages and planktonic foraminifer zones give the uncertainty interval of boundaries caused by sampling density and poor preservation, respectively. 


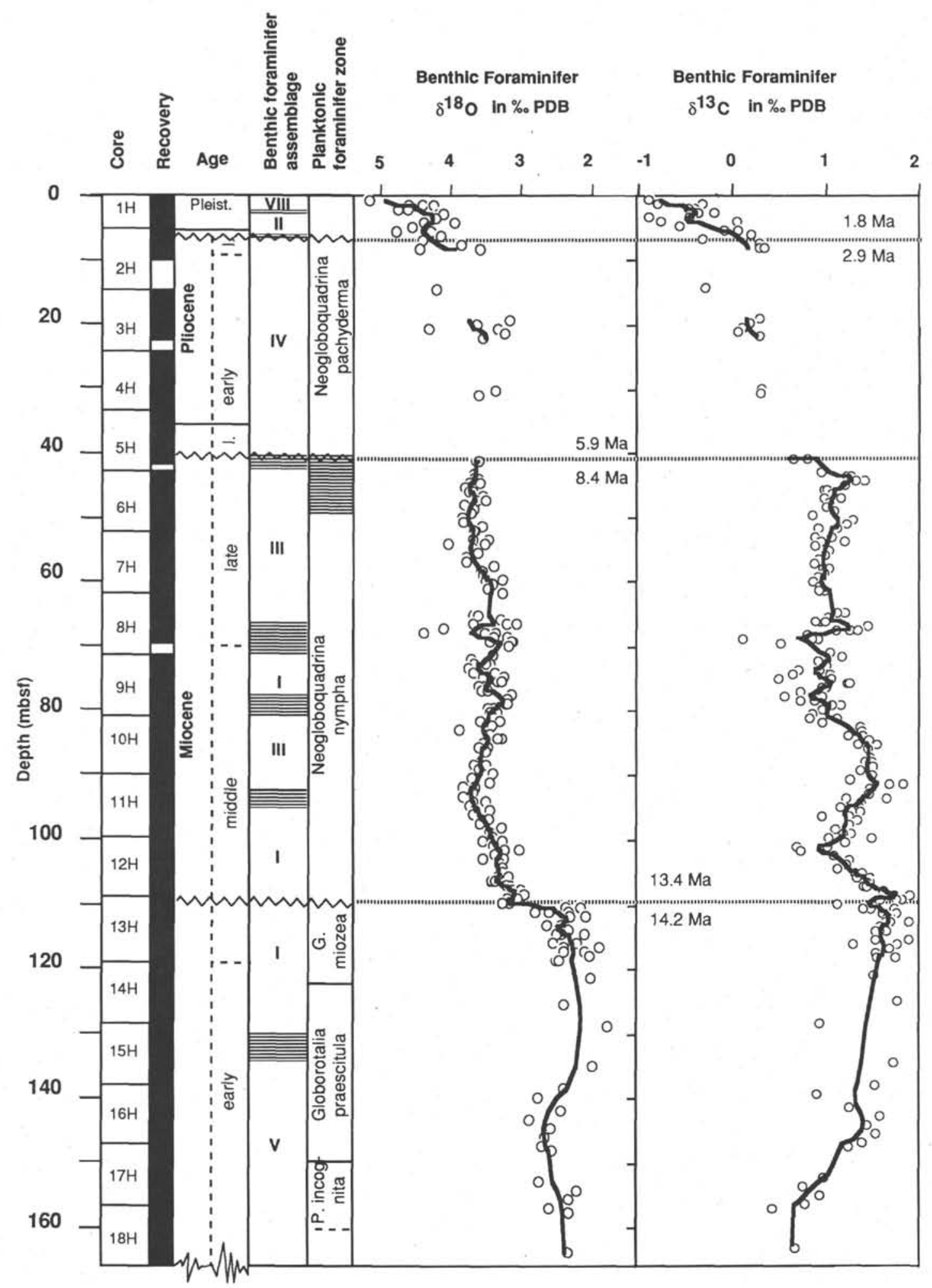

Figure 3. Smoothed benthic oxygen and carbon isotope data are plotted vs. sub-bottom depth, benthic foraminifer assemblages (Mackensen, this volume), and planktonic foraminifer zones (Berggren, this volume). Raw data are indicated by open circles. The curves represent average values obtained by a weighted 11-point running average. Age determinations are according to the Shipboard Scientific Party (Schlich, Wise, et al., 1989) with modifications by Harwood and Maruyama (this volume), Berggren (this volume), Heider et al. (this volume), and this paper (see discussion in "Stratigraphy and Age Model" section). The multiple lines between benthic foraminifer assemblages and planktonic foraminifer zones give the uncertainty interval of boundaries caused by sampling density and poor preservation, respectively. 


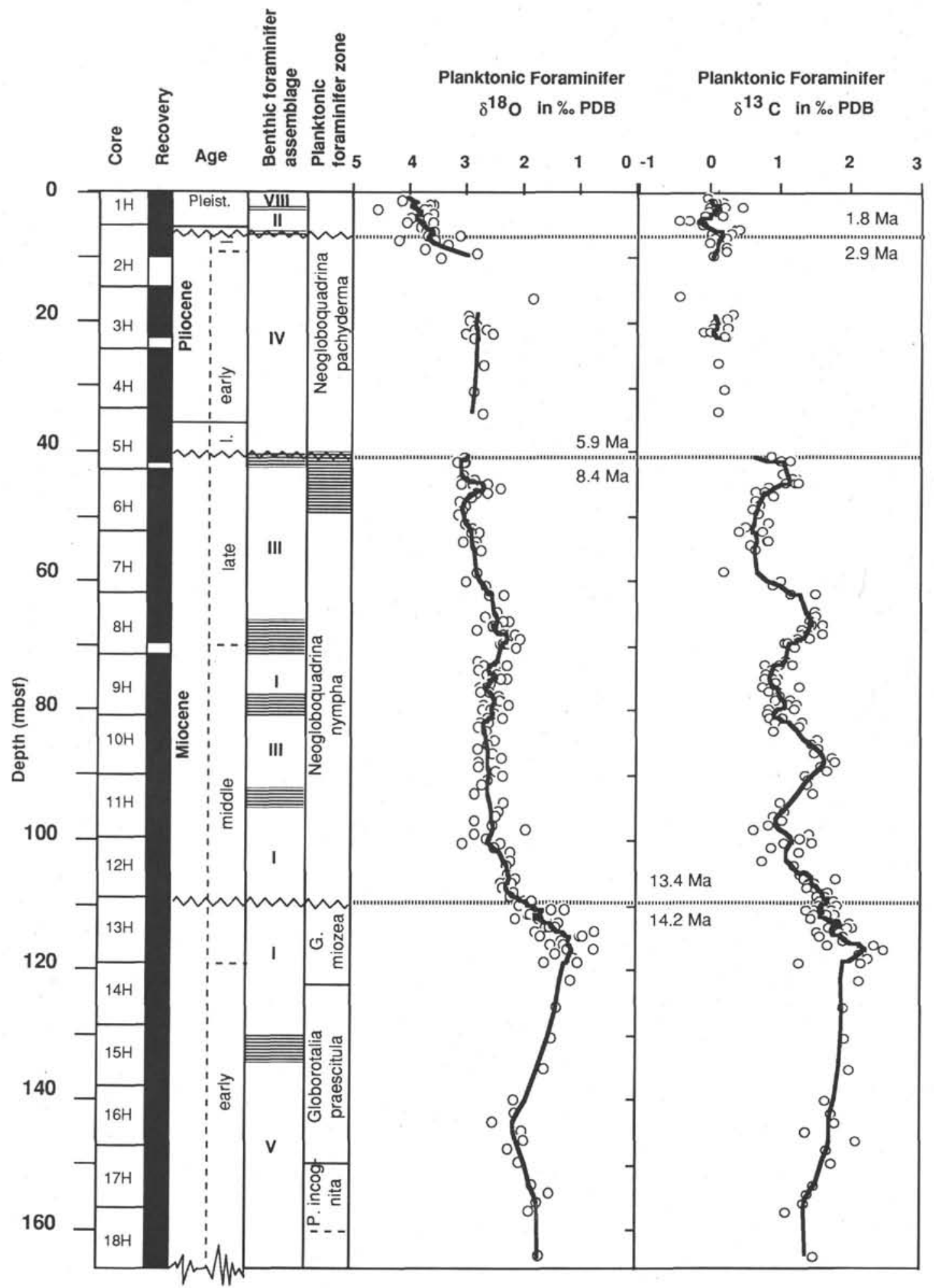

Figure 4. Smoothed planktonic oxygen and carbon isotope data are plotted vs. sub-bottom depth, benthic foraminifer assemblages (Mackensen, this volume), and planktonic foraminifer zones (Berggren, this volume). Raw data are indicated by open circles. The curves represent average values obtained by a weighted 11-point running average. Age determinations are according to the Shipboard Scientific Party (Schlich, Wise, et al., 1989) with modifications by Harwood and Maruyama (this volume), Berggren (this volume), Heider et al. (this volume), and this paper (see discussion in "Stratigraphy and Age Model" section). The multiple lines between benthic foraminifer assemblages and planktonic foraminifer zones give the uncertainty interval of boundaries caused by sampling density and poor preservation, respectively. 
Table 3. Preliminary assignments of Miocene oxygen isotope events to depth (mbsf), Hole 751A.

\begin{tabular}{llrr}
\hline Event & \multicolumn{1}{c}{ Author } & $\begin{array}{c}\text { Age } \\
\text { (Ma) }\end{array}$ & $\begin{array}{r}\text { Depth } \\
\text { (mbsl) }\end{array}$ \\
\hline MI6 & Miller et al. & 9.6 & 67 \\
MI4 & Miller et al. & 12.6 & 106 \\
F & Woodruff and Savin & 13.4 & 109 \\
D & Woodruff and Savin & 14.9 & 114 \\
MI2 & Miller et al. & 16.1 & 118 \\
MI1c & Wright and Miller & 18.1 & 140 \\
\hline
\end{tabular}

ume) and magnetic polarities (Heider et al., this volume), and a third one at the Pliocene/Pleistocene boundary from 2.9 to 1.8 Ma (Harwood and Maruyama, this volume).

\section{RESULTS OF BENTHIC FAUNAL ANALYSES}

The following benthic foraminifer assemblages were recognized in the Neogene sedimentary sequence of Hole 751A (for comparison and a complete faunal description, also see Mackensen, this volume):

PC V: Uvigerina hispidocostata Assemblage

Age: middle early Miocene

Depth: $166.20-134.56$ mbsf

Dominant and/or characteristic species: $U$. hispidocostata, Nuttallides umbonifer

PC I: Nuttallides umbonifer Assemblage

Age: late early Miocene through middle Miocene and early late Miocene

Depth: $130.06-95.42$ and $77.92-71.20$ mbsf

Dominant and/or characteristic species: N. umbonifer

PC III: Astrononion pusillum Assemblage

Age: late middle Miocene and middle late Miocene

Depth: $92.42-80.70$ and $66.92-42.70 \mathrm{mbsf}$

Dominant and/or characteristic species: A. pusillum (no N. umbonifer)

PC IV: Epistominella exigua Assemblage

Age: latest late Miocene through late Pliocene

Depth: $40.70-6.56 \mathrm{mbsf}$

Dominant and/or characteristic species: $E$. exigua

(Martinotiella nodulosa, Eggerella bradyi, and Karreriella bradyi)

PC II: Trifarina angulosa Assemblage

Age: early Pleistocene

Depth: 6.14-2.80 mbsf

Dominant and/or characteristic species: $T$. angulosa (no Bulimina aculeata)

PC VIII: Bulimina aculeata Assemblage

Age: late early Pleistocene through Holocene

Depth: 2.32-0 mbsf

Dominant and/or characteristic species: B. aculeata,

T. angulosa

\section{RESULTS OF HIGH-RESOLUTION CARBONATE DETERMINATION}

The inorganic carbon content, expressed as weight percent carbonate, varies considerably with depth at Site 751. Values range from near zero in the upper Pliocene sediments to $>90 \%$ toward the bottom of the hole in the lower Miocene (Figs. 1 and 2).
Miocene samples (165-40 mbsf) have carbonate contents of $40 \%-90 \%$. A distinct drop in carbonate content in the lower middle Miocene at $109.14 \mathrm{mbsf}$ is associated with a major unconformity (14.2-13.4 Ma), whereas no unconformity is found associated with a similar drop in carbonate content at 115.05 mbsf. The lowermost upper Miocene sediments between 75.7 and $66.9 \mathrm{mbsf}$, and a sequence in the lower middle Miocene from 102.7 to 99.8 mbsf have consistently low carbonate contents $(40 \% \pm 10 \%)$.

The Pliocene-Pleistocene sediments (40-0 mbsf) are characterized by low to moderate carbonate contents $(10 \%-70 \%)$ in the upper part of the section between the mud line and 8.8 mbsf, and extremely low $\mathrm{CaCO}_{3}$ contents in the lower part, down to 39.9 mbsf. Discrete intervals of higher carbonate contents (up to 28\%) are scattered within the lower section from 18.3 to $21.7,29.3$ to 30.4 , and 33.2 to 33.6 mbsf.

\section{OXYGEN AND CARBON ISOTOPE RESULTS}

\section{Benthic $\boldsymbol{\delta}^{18} \mathbf{O}$ Values}

The benthic oxygen isotope record at Site 751 (Figs. 1 and 3) exhibits a number of steps that represent changing average values over specific depth (time) intervals. The smoothed curve (Fig. 3) suggests a roughly fourfold division of this record: (1) a middle lower Miocene section (170-140 mbsf) with average values around $2.9 \%$; (2) an upper lower Miocene to lowermost middle Miocene section (140-110 mbsf) with depleted values that average around $2.4 \%$; (3) a middle through upper Miocene section (110-40 mbsf) with abruptly increased average values around $3.9 \%$; and, finally, (4) an upper Pliocene-Pleistocene section (10-0 mbsf) with highly fluctuating amplitudes between $3.2 \%$ and $5.0 \%$.

Following the rapid enrichment in the lower middle Miocene, which is associated here with a hiatus of $0.8 \mathrm{~m} . \mathrm{y}$., a gradual enrichment in $\delta^{18} \mathrm{O}(0.5 \%$ avg.) occurs between 100 and 91 mbsf, followed by a small depletion between 91 and 75 mbsf. Above these fairly stable trends (75-67 mbsf), a lower upper Miocene section with highly varying $\delta^{18} \mathrm{O}$ values $( \pm 0.4 \%$ ) follows, which corresponds to a core interval of reduced carbonate contents. Within the upper Miocene, at 60 mbsf, the smoothed curve indicates an increase in average $\delta^{18} \mathrm{O}$ values, which coincides with a strong $\delta^{13} \mathrm{C}$ depletion of the planktonic isotopic composition of Globigerina bulloides (Figs. 3 and 4).

\section{Planktonic $\delta^{18} \mathbf{O}$ Values}

Generally, the fourfold division of the benthic $\delta^{18} \mathrm{O}$ curve can be applied to the planktonic $\delta^{18} \mathrm{O}$ record (Figs. 1 and 4) as well: (1) a middle lower Miocene section with gradually enriched values and maximum values around $143 \mathrm{mbsf}$; followed by (2) a depletion of average values of $1 \%$ toward the uppermost Miocene. (3) After a sharp enrichment of average $\delta^{18} \mathrm{O}$ values just before the lower middle Miocene hiatus, average values oscillate around $2.5 \%$ through middle and upper Miocene sections upcore to $60 \mathrm{mbsf}$. Above this, a gradual enrichment from $3.0 \%$ to $3.3 \%$ occurs up to $40 \mathrm{mbsf}$, interrupted by a distinct light excursion of smoothed values of more than $0.6 \%$ around $45 \mathrm{mbsf}$. (4) The upper Pliocene and Pleistocene section from 10 mbsf to the mud line exhibits strongly varying values between $3.1 \%$ and $4.7 \%$ with abruptly increasing values $(1 \%)$ at 10 mbsf.

\section{Benthic $\boldsymbol{\delta}^{13} \mathbf{C}$ Values}

The benthic $\delta^{13} \mathrm{C}$ curve (Figs. 2 and 3) depicts a trend of decreasing values from the lower Miocene to upper Pleistocene by $\approx 2 \%$. Overlaid upon this trend are two distinct excursions toward higher values. 


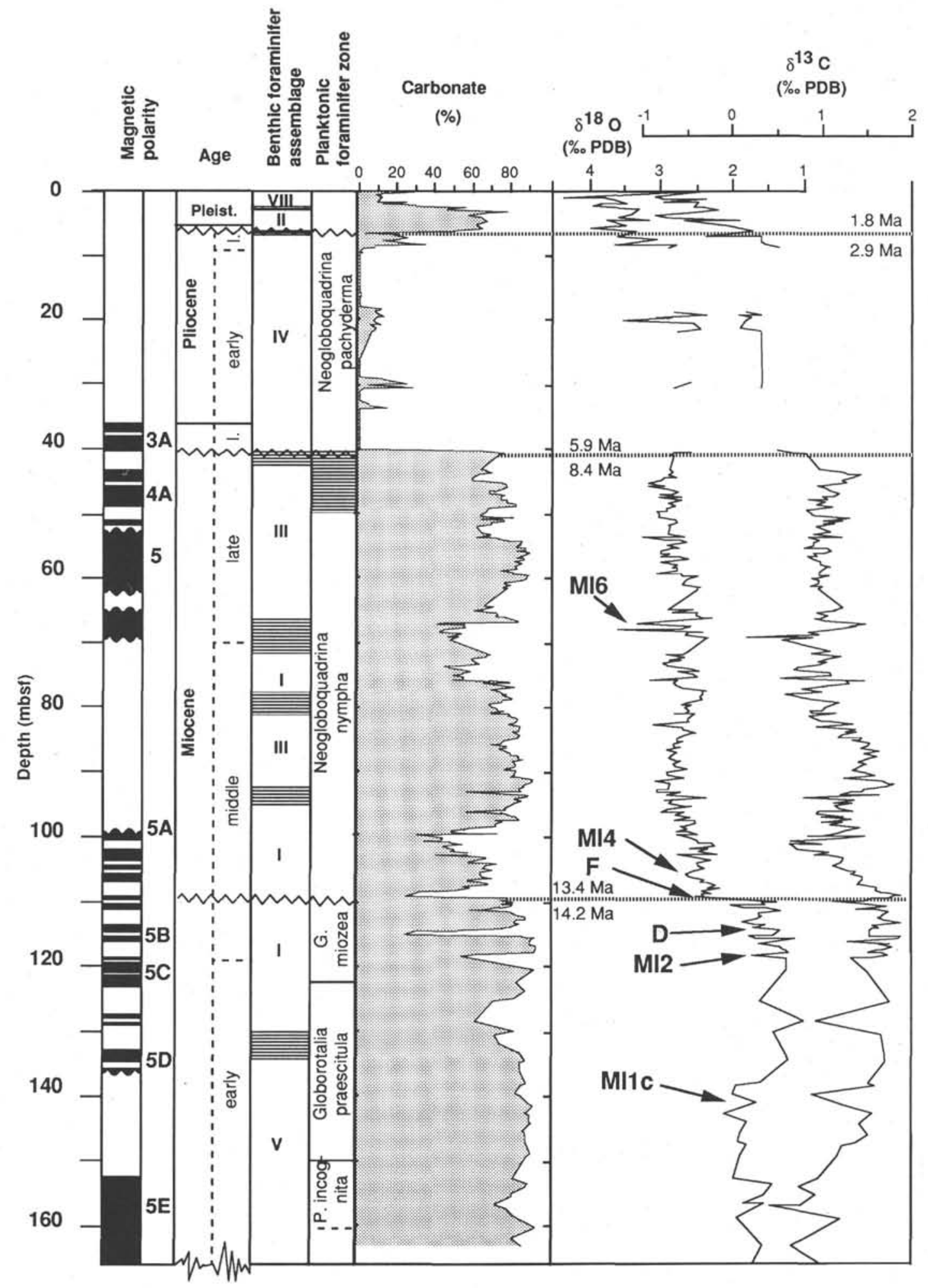

Figure 5. Benthic oxygen and carbon isotope data are plotted vs. sub-bottom depth, magnetic polarities (data from Heider et al., this volume), benthic foraminifer assemblages (Mackensen, this volume), and planktonic foraminifer zones (Berggren, this volume). Age determinations are according to the Shipboard Scientific Party (Schlich, Wise, et al., 1989) with modifications by Harwood and Maruyama (this volume), Berggren (this volume), Heider et al. (this volume), and this paper (see discussion in "Stratigraphy and Age Model" section). The multiple lines between benthic foraminifer assemblages and planktonic foraminifer zones give the uncertainty interval of boundaries caused by sampling density and poor preservation, respectively. Distinct Miocene isotope events (MI1c, MI2, MI4, MI6, F, and D) are indicated and preliminarily assigned to the isotope stratigraphies of Miller et al. (1991), Wright and Miller (this volume), and Woodruff and Savin (in press), respectively. 
One excursion ranges from 155 to 100 mbsf. From average values of $0.8 \%$ at the bottom of the hole, the $\delta^{13} \mathrm{C}$ smoothed values gradually increase between 155 and 140 mbsf to $1.6 \%$. Average values around $1.6 \%$ continue to shortly below the hiatus in the early middle Miocene (109 mbsf), where the smoothed curve (Fig. 3 ) depicts an abrupt decrease of $0.3 \%$, immediately followed by an abrupt increase in $\delta^{13} \mathrm{C}$ values within the low-carbonate horizon, which supposedly coincides with the hiatus (Fig. 2). Above the disconformity $(<109$ mbsf), the $\delta^{13} \mathrm{C}$ values gradually become lower by $1.3 \%$ with a minimum of $0.6 \%$ at 101 mbsf.

Between 100 and $80 \mathrm{mbsf}$, the second excursion to enriched $\delta^{13} \mathrm{C}$ values occurs, centered at $91 \mathrm{mbsf}$, with values of $1.9 \%$. Between 80 and $65 \mathrm{mbsf}, \delta^{13} \mathrm{C}$ values vary strongly with an amplitude of $\approx 1 \%$. Above this, a section follows with quite stable average values around $1 \%$ up to $45 \mathrm{mbsf}$. In the uppermost Miocene at $45 \mathrm{mbsf}, \delta^{13} \mathrm{C}$ values increase by $\approx 0.5 \%$ to $1.5 \%$ and then abruptly decrease toward $40 \mathrm{mbsf}$ by $\approx 1 \%$ to $0.5 \%$. The upper Pliocene and Pleistocene $(10-0$ mbsf) is characterized by heavily depleted values ranging from $0.5 \%$ to $-0.9 \%$.

\section{Planktonic $\boldsymbol{\delta}^{\mathbf{1 3}} \mathbf{C}$ Values}

The planktonic carbon isotope record (Figs. 2 and 4) depicts a dominant trend of decreasing $\delta^{13} \mathrm{C}$ values throughout the sedimentary sequence, from lower Miocene to upper Pleistocene by $\approx 2 \%$.

Overlaid upon this trend are several distinct excursions toward higher values. The first excursion between 155 to 100 mbsf parallels the one observed in the benthic carbon isotope record. In contrast to the benthic record, no significantly decreased values just below the hiatus at 109 mbsf are indicated. There was a depletion from average values of $2 \% \circ$ in late early Miocene time to average values of $1 \%$ in early middle Miocene time. Below the middle Miocene hiatus, $\delta^{13} \mathrm{C}$ values of planktonic foraminifers are generally $0.5 \%$ o higher than the carbon isotopic composition of Cibicidoides spp. The second excursion toward $\delta^{13} \mathrm{C}$-enriched values between 100 and $80 \mathrm{mbsf}$ also parallels the benthic values, but in contrast to an older excursion, the absolute $\delta^{13} \mathrm{C}$ values differ only slightly and randomly from the benthic carbon isotope composition. The third excursion, between 75 and $60 \mathrm{mbsf}$, is similar to the second one. The planktonic foraminifers, however, are again consistently more enriched in ${ }^{13} \mathrm{C}$ than the benthic foraminifers. Between 60 and 45 mbsf, the average planktonic carbon isotope composition is depleted by $\approx 0.3 \%$ compared to the benthic values. Above this sequence, the fourth excursion of the planktonic $\delta^{13} \mathrm{C}$ parallels the benthic curve again in both trend and absolute values.

Between 40 and 4 mbsf the planktonic isotope composition is depleted by $0.6 \%$ compared to the last pre-Pliocene values. During Pleistocene time planktonic values oscillated between $-0.3 \%$ and $0.7 \%$, keeping a persistent difference to the lower benthic carbon isotope composition of almost $1 \%$.

\section{DISCUSSION}

\section{Miocene}

The $\delta^{18} \mathrm{O}$ values show the worldwide observed trend of increasing values toward the end of the early Miocene (e.g., Savin et al., 1981; Miller et al., 1987a). Assuming a substantially ice-free earth (Shackleton and Kennett, 1975; Savin et al., 1975), this implies a warming of approximately $3^{\circ} \mathrm{C}$ of both the bottom- and surface-water masses. However, in more recent studies, it is widely argued that large continental ice sheets have existed at least since the earliest Oligocene (Matthews and Poore, 1980; Miller et al., 1987a; Hambrey et al., 1991; Ehrmann, 1991; Zachos et al., this volume; among others), and perhaps since the late Eocene (Prentice and Matthews, 1988; Hambrey et al., 1989; Barron, Larsen, et al., 1989). Therefore, we cannot separate temperature from icevolume effects before $15 \mathrm{Ma}$ (see Williams et al., 1988).

Middle lower Miocene sediments recovered in the deepest parts of Hole 751A are characterized by a Uvigerina-dominated benthic foraminifer fauna (PC VI), high carbonate content, and fairly low $\delta^{13} \mathrm{C}$ values of both planktonic and benthic foraminifers, but high $\Delta \delta^{13} \mathrm{C}$ values ${ }^{813} \mathrm{C}$ planktonic${ }^{813 C}$ benthic). Generally, the differences between planktonic and benthic d13C values were consistently large before 14.2 $\mathrm{Ma}$. This indicates a stratification of water masses so that the nutrient-depleted, $\delta^{13} \mathrm{C}$-enriched, surface-water clearly differed from old, $\delta^{13} \mathrm{C}$-depleted intermediate waters, which bathed the Southern Kerguelen Plateau before the intensified buildup of the East Antarctic ice sheet in the early middle Miocene. Alternatively, high $\Delta \delta^{13} \mathrm{C}$ values may indicate a highly productive area (Berger and Vincent, 1986), possibly as a result of the upwelling of deep Indian Ocean water (Woodruff and Savin, 1989). The hypothesis of high productivity is strongly corroborated by the Uvigerina-dominated benthic foraminifer fauna (PC V), which is known to prefer a high organic matter supply and which tolerates the resulting lowoxygen pore-water conditions (Miller and Lohmann, 1982; Lutze and Coulbourn, 1984; Mackensen, this volume).

The so-called middle Miocene cooling event is documented by an increase in mean $\delta^{18} \mathrm{O}$ values of both benthic and planktonic foraminifers by $1.2 \%$. If a buildup of an ice volume equivalent to modern values is assumed, the increase of $\delta^{18} \mathrm{O}$ values by more than $1 \%$ must have been caused by an additional drop in water temperature. The hiatus from 14.2 to 13.4 $\mathrm{Ma}$, associated with this boundary may indicate an intensification of the circumpolar surface-water circulation, which in turn followed increasing circumpolar wind velocities, caused by polar cooling and increased temperature gradients between low and high latitudes. On the Maud Rise at Sites 689 and 690 , however, sediments representing the time span from 14.9 to $11.55 \mathrm{Ma}$ are present, but barren of benthic foraminifers (Thomas, 1990).

Principal Component I, dominated by Nuttallides umbonifer characterizes the fauna throughout the upper lower and lower middle Miocene across the hiatus and the middle Miocene cooling event, up to $94.5 \pm 1.5$ mbsf. Above this, an Astrononion pusillum assemblage (PC III) takes over between 94.5 and $80.5 \pm 1.5 \mathrm{mbsf}$, followed by a PC I interval between 80.5 and $69 \pm 2$ mbsf that clearly coincides with an excursion toward low carbonate content and an increase in mean $\Delta \delta^{13} \mathrm{C}$ values around $10 \mathrm{Ma}$ (Figs. 1-5; see also Mackensen, this volume). Generally, N. umbonifer is thought to prefer water masses corrosive relative to carbonate (Bremer and Lohmann, 1982; Corliss, 1983), including old and $\mathrm{CO}_{2}$-rich water masses (Thomas, 1985). In the southeastern Weddell Sea, a Holocene $N$. umbonifer-dominated fauna is restricted to the zone between the carbonate lysocline and the carbonate compensation depth (CCD), which there corresponds to the upper part of the AABW (Mackensen et al., 1990). In the modern Indian Ocean, $N$. umbonifer is associated with cold AABW (Corliss, 1979).

The downcore distribution of PC I, and of N. umbonifer in particular, indicates that intermediate- and bottom-water circulation at Kerguelen Plateau changed considerably after the middle Miocene global cooling, and that conditions similar to those in the late early Miocene were reestablished temporarily around the middle/late Miocene boundary. The data indicate that a faunal turnover of benthic foraminifers in the early middle Miocene did not take place simply in response to a 
global bottom-water cooling. Rather, the benthic foraminifers reflect changes in a set of specific environmental conditions, which may include bottom-water cooling, but which are primarily caused by global climatic and tectonic changes (Douglas and Woodruff, 1981; Woodruff et al., 1981; Woodruff and Savin, 1989). This is in agreement with conclusions based on Deep Sea Drilling Project (DSDP) Sites 573, 574, and 575 from the equatorial Pacific Ocean, where benthic foraminifer faunas started to change several millions of years before the middle Miocene cooling (Thomas, 1985; Thomas and Vincent, 1987).

An excursion toward high carbon isotope values spanning the early/middle Miocene boundary between about 18 and 12 Ma (possibly including the "Monterey event" of Vincent and Berger [1985] from 16.4 to 14 Ma [Woodruff and Savin, in press]), is evident in both the planktonic and the benthic record. In our data set, this time interval is interrupted by a hiatus from about 14.2 to $13.4 \mathrm{Ma}$, but the benthic record clearly depicts a sharp decrease shortly before the hiatus coinciding with the major increase in $\delta^{18} \mathrm{O}$ values. This decrease in $\delta^{13} \mathrm{C}$ values probably indicates the beginning of the $0.8 \%$ o decrease at the end of the Monterey excursion at $14 \mathrm{Ma}$ (Woodruff and Savin, in press), which in Site 751 data is not completely recorded because of the hiatus between 14.2 and 13.4 Ma. This also correlates with published DSDP records from the North Atlantic Sites 563 and 608 (Miller and Fairbanks, 1985; Miller et al., 1987b) and South Pacific Site 289 (redrafted in Williams et al., 1988; data in Savin et al., 1981; Shackleton, 1982; see also Wright and Miller, this volume; Miller et al., 1991; and Woodruff and Savin, in press).

A benthic foraminifer assemblage dominated by $A$. pusillum (PC III) was present during a time span in the middle Miocene and then consistently from the early late Miocene $(\approx 9.6 \mathrm{Ma})$ to the hiatus around $8.4 \mathrm{Ma}$. This fauna is correlated with an input of a water mass similar in composition to NADW, into the circumpolar ocean (Mackensen, this volume). Average benthic $\delta^{13} \mathrm{C}$ values around $1 \%$ o during this time span, which are significantly lower than during the "Monterey excursion," give some support for the assumption of the influence of an aged, ${ }^{13} \mathrm{C}$-depleted water mass. This may also agree with conclusions by Woodruff and Savin (1989) that before $11 \mathrm{Ma}$ NADW formation was weak, but that thermohaline circulation resembled modern circulation from $10 \mathrm{Ma}$ to the end of the Miocene.

Site $751 \delta^{18} \mathrm{O}$ values show an abrupt temporary decrease of $0.8 \%$ of the planktonic $\delta^{18} \mathrm{O}$ and a coincident less significant increase of $0.5 \%$ of the benthic curve at $\approx 8.6 \mathrm{Ma}$ just before the hiatus between $\approx 8.4$ to $5.9 \mathrm{Ma}$ (Harwood and Maruyama, this volume). One hypothesis explaining this peculiar pattern may be a short $(0.2-0.3 \mathrm{~m} . \mathrm{y}$.) climatic amelioration: a worldwide period of fairly high sea level occurred between 9.5 and 8.2 Ma (Haq et al., 1987). Before a minor regression at $8.2 \mathrm{Ma}$ (Haq et al., 1987), around $8.6 \mathrm{Ma}$, low planktonic $\delta^{18} \mathrm{O}$ values indicate warm surface waters and possibly a local influence of meltwater from the shelf ice, also the grounding line retreated behind the shelf break and, because of high sea-level stand, the ice shelf was floating. Simultaneously, increased benthic $\delta^{18} \mathrm{O}$ values indicate cool bottom water caused by an increased bottom-water production beneath the floating ice shelf.

Then, the climate deteriorated, causing an increase in ice volume, a lowering of the sea level, and erosion or nondeposition on wide parts of the Kerguelen Plateau. Finally, during the time of nondeposition (i.e., at the hiatus from $\approx 8.4$ to $5.9 \mathrm{Ma}$ ), this led to the turnover from benthic foraminifer assemblage III, dominated by Astrononion pusillum, to assemblage IV, dominated by Epistominella exigua (Mackensen, this volume). E. exigua is an epibenthic phytodetritus feeder (Gooday, 1988), which in high-latitude environments is associated with high productivity (Mackensen et al., 1985, 1990). Dominance of the $E$. exigua assemblage indicates that the Polar Frontal Zone moved northward and strongly influenced the Southern Kerguelen Plateau, as a result of cooling and increasing ice volume.

\section{Pliocene and Pleistocene}

An Epistominella exigua-dominated benthic foraminifer fauna (PC IV) appeared at the hiatus between $\approx 8.4$ and 5.9 $\mathrm{Ma}$, slightly before an abrupt drop in $\mathrm{CaCO}_{3}$ content from $75 \%$ to almost $0 \%$. This fauna is found up into upper Pliocene sediments, alternating with carbonate-free sediments. This fauna is interpreted as a residual benthic foraminifer assemblage, resulting from severe carbonate dissolution (Mackensen et al., 1990) under a high productivity belt associated with the Polar Frontal Zone (Mackensen, this volume).

In the late Pliocene and early Pleistocene, both benthic and planktonic $\delta^{18} \mathrm{O}$ values as well as benthic $\delta^{13} \mathrm{C}$ values increased rapidly. In contrast, planktonic $\delta^{13} \mathrm{C}$ did not change much. Thus, the $\Delta \delta^{13} \mathrm{C}$ values $\left({ }^{813} \mathrm{C}\right.$ planktonic- ${ }^{813} \mathrm{C}$ benthic) drastically increased, indicating stratification within the water masses and/or a highly effective photic carbon pump (productivity signal). These changes coincide with a hiatus between 2.9 and $1.8 \mathrm{Ma}$, and thus fall within the time span of the onset of major glaciation in the Northern Hemisphere around 2.6 Ma (Jansen et al., 1989; Bohrmann et al., 1990). At the same time, the benthic foraminifer fauna became dominated by Trifarina angulosa (PC II), which prefers sandy substrates with moderate to strong bottom currents. Today, around Antarctica, this fauna is associated with areas strongly influenced by the ACC (Mackensen et al., 1990). In summary, the changes in benthic foraminifer composition and the $\Delta \delta^{13} \mathrm{C}$ variations in the upper Pliocene indicate a change in bottom-water mass chemistry and surface productivity, as well as increased bottom current activity. These changes may reflect the worldwide climatic deterioration and lowering of the sea level at the initiation of northern hemisphere glaciation.

The late Pleistocene ( $<1 \mathrm{Ma})$ is characterized by a Bulimina aculeata fauna (PC VIII). Today, in high-latitude environments, this fauna is an indicator of calm depositional regimes with clayey and organic-rich sediments, often associated with a water-mass boundary, such as below a current system that flows parallel to a continental margin (Mackensen et al., 1990, this volume). This coincides with the observed reduced carbonate content in the uppermost part of the sediment column in Hole 751A and implies, in combination with the very high $\Delta \delta^{13} \mathrm{C}$ values, high siliceous primary productivity close to the Polar Frontal Zone.

\section{SUMMARY AND CONCLUSIONS}

At the time that this paper was written, great discrepancies in views of the stratigraphy of Site 751 occurred between different biostratigraphers. Therefore, we kept paleoceanographic interpretations and conclusions to a minimum to avoid speculation, which may turn out to be nonsense after readjustment of the stratigraphy.

1. Middle Miocene oxygen and carbon isotope data of Site 751 carry valuable stratigraphic information and so provide an additional tool for correlation of this site with the global Miocene stratigraphy. Preliminary correlation with published data from North Atlantic DSDP Sites 563 and 608 and Leg 120 Site 747, as well as with records from South Pacific Site 289, yielded the recognition of distinct features in the benthic $\delta^{18} \mathrm{O}$ record, which we preliminarily assigned to recently published Miocene stable isotope event stratigraphies (Table 3). 
2. At the Kerguelen Plateau, a $N$. umbonifer-dominated fauna persisted from $\approx 17.5$ to $\approx 11 \mathrm{Ma}$, interrupted by one short hiatus (and possibly more); consequently, there was no major benthic foraminifer faunal change associated with the middle Miocene cooling event between 14.9 and $14.2 \mathrm{Ma}$. Thus, there is no evidence from benthic foraminifers for a major change in bottom-water circulation in the vicinity of East Antarctica at that time.

3. From $\approx 11$ to a hiatus at $8.4 \mathrm{Ma}$, a benthic foraminifer fauna dominated by $A$. pusillum took over, interrupted by a short period around $10 \mathrm{Ma}$ when $N$. umbonifer and a coinciding interval of reduced carbonate content indicated the reestablishment of a carbonate aggressive bottom-water mass. The final shift to the $A$. pusillum fauna at $\approx 9.6 \mathrm{Ma}$ is interpreted to indicate the injection of a water mass similar to the NADW into the ACC, possibly correlated to the glaciation of West Antarctica and the buildup of the continental ice shelves in the southern Weddell Sea and the Ross Sea.

4 . From $\approx 5.8 \mathrm{Ma}$ through the early Pliocene, carbonatefree sediments or sediments with only low $\mathrm{CaCO}_{3}$ content were associated with an E. exigua-dominated fauna or its corresponding arenaceous residual fauna, indicating that a high biogenic siliceous productivity zone, such as the Polar Frontal Zone, was situated above the Southern Kerguelen Plateau.

5. A hiatus from $\approx 2.9$ to $1.8 \mathrm{Ma}$ and the benthic faunal change from an E. exigua fauna to a $T$. angulosa Assemblage strongly indicate high bottom current activity since the late Pliocene. Current velocities probably increased coeval with the beginning of the major glaciation in the Northern Hemisphere around $2.6 \mathrm{Ma}$.

6. The late Pleistocene benthic foraminifer assemblage ( $B$. aculeata) indicates a calm depositional regime with clayey and organic-rich sedimentation from a highly productive photic zone. This agrees well with lower carbonate contents and high differences between planktonic and benthic $\delta^{13} \mathrm{C}$ values.

\section{ACKNOWLEDGMENTS}

We thank the master and crew of the JOIDES Resolution and the ODP technical staff for their work and assistance on board ship. We also thank M. Heyn and A. Wolf for technical assistance. G. Meyer took care of the mass spectrometer. We are grateful to W. U. Ehrmann for discussions and reviewing of an early draft of this manuscript. The reviews and comments of S. M. Savin, E. Thomas, and F. Woodruff are gratefully acknowledged. Financial support was provided by Deutsche Forschungsgemeinschaft to A. M. and by National Science Foundation Grant No. OCE- 8800049 to E. B. This is Alfred Wegener Institute Contribution No. 328.

\section{REFERENCES}

Barker, P. F., Kennett, J. P., and Leg 113 Shipboard Scientific Party, 1988. Weddell Sea palaeoceanography: preliminary results of ODP Leg 113. Palaeogeogr., Palaeoclimatol., Palaeoecol., 67:75-102.

Barrera, E., Keller, G., and Savin, S. M., 1985. Evolution of the Miocene ocean in the eastern North Pacific as inferred from oxygen and carbon isotopic ratios of foraminifera. Mem. Geol. Soc. Am., 163:83-102.

Barrett, P. J. (Ed.), 1989. Antarctic Cenozoic history from the CIROS-1 drillhole, McMurdo Sound. DSIR Bull., 245.

Barron, J., Larsen, B., et al., 1989. Proc. ODP, Init. Repts., 119: College Station, TX (Ocean Drilling Program).

Berger, W. H., and Vincent, E., 1986. Deep-sea carbonates: reading the carbon-isotope signal. Geol. Rundsch., 75:249-269.

Berggren, W. A., Kent, D. V., and Van Couvering, J. A., 1985. The Neogene: Part 2. Neogene geochronology and chronostratigraphy. In Snelling, N. J. (Ed.), The Chronology of the Geological Record. Geol. Soc. London Mem., 10:211-260.
Bohrmann, G., Henrich, R, and Thiede, J., 1990. Miocene to Quaternary paleoceanography in the northern North Atlantic: indications by changes in carbonate and biogenic opal accumulation. In Bleil, U., and Thiede, J. (Eds.), Geological History of the Polar Oceans: Arctic versus Antarctic. NATO ASI Series C, Kluwer Acad. Publ., 647-675.

Bremer, M. L., and Lohmann, G. P., 1982. Evidence for primary control of the distribution of certain Atlantic Ocean benthonic foraminifera by degree of carbonate saturation. Deep-Sea Res. Pt. A, 29:987-988.

Broecker, W. S., Takahashi, T., and Takahashi, T., 1985. Sources and flow patterns of deep-ocean waters as deduced from potential temperature, salinity, and initial phosphate concentration. J. Geophys. Res., 90:6925-6939.

Ciesielski, P. F., Ledbetter, M. T., and Ellwood, B. B., 1982. The development of Antarctic glaciation and the Neogene paleoenvironment of the Maurice Ewing Bank. Mar. Geol., 46:1-51.

Corliss, B. H., 1979. Recent deep-sea benthonic foraminifer distributions in the southeast Indian Ocean: inferred bottom-water routes and ecological implications. Mar. Geol., 31:115-138.

1983. Distribution of Holocene deep-sea benthonic foraminifera in the southwest Indian Ocean. Deep-Sea Res., Pt. A, 30:95-117.

Deacon, G.E.R., 1983. Kerguelen, Antarctic and subantarctic. DeepSea Res., Pt. A, 30:77-81.

Douglas, R. G., and Savin, S. M., 1975. Oxygen and carbon isotope analyses of Tertiary and Cretaceous microfossils from Shatsky Rise and other sites in the North Pacific Ocean. In Larson, R. L., Moberly, R., et al., Init. Repts. DSDP, 32: Washington (U.S. Govt. Printing Office), 509-520.

Douglas, R. G., and Woodruff, F., 1981. Deep-sea benthic foraminifera. In Emiliani, C. (Ed.), The Sea (Vol. 7): New York (WileyInterscience), 1233-1327.

Ehrmann, W. U., 1991. Implications of sediment composition on the Southern Kerguelen Plateau for paleoclimate and depositional environment. In Barron, J., Larsen, B., et al., Proc. ODP, Sci. Results, 119: College Station, TX (Ocean Drilling Program), 185-210.

Emery, W. J., and Meincke, J., 1986. Global water masses: summary and review. Oceanol. Acta, 9:383-391.

Foldvik, A., and Gammelsrød, T., 1988. Notes on Southern Ocean hydrography, sea-ice and bottom water formation. Palaeogeogr., Palaeoclimatol., Palaeoecol., 67:3-17.

Foldvik, A., Gammelsrød, T., and Tørresen, T., 1985. Circulation and water masses on the southern Weddell Sea Shelf. Antarct. Res. Ser., 43:5-20.

Gooday, A. J., 1988. A response by benthic foraminifera to the deposition of phytodetritus in the deep sea. Nature, 332:70-73.

Hambrey, M., Ehrmann, W. U., and Larsen, B., 1991. Cenozoic glacial record of the Prydz Bay Continental Shelf, East Antarctica. In Barron, J., Larsen, B., et al., Proc. ODP, Sci. Results, 119: College Station, TX (Ocean Drilling Program), 77-132.

Hambrey, M. J., Larsen, B., Ehrmann, W. U., and ODP Leg 119 Shipboard Scientific Party, 1989. Forty million years of Antarctic glacial history yielded by Leg 119 of the Ocean Drilling Program. Polar Rec., 25:99-106.

Haq, B. U., Hardenbol, J., and Vail, P. R., 1987. Chronology of fluctuating sea levels since the Triassic. Science, 235:1156-1167.

Hellmer, H., and Bersch, M., 1985. The Southern Ocean: a survey of oceanographic and marine meteorological research work. Ber. Polarforsch., 26:1-115.

Hemleben, C., Spindler, M., and Anderson, O. R., 1989. Modern Planktonic Foraminifera: Berlin (Springer-Verlag).

Hut, G., 1987. Stable isotope reference samples for geochemical and hydrological investigations. Rept. to the Director General, Inter. Atomic Energy Agency, Vienna, 16-18 Sept. 1985.

Jansen, E., Slettemark, B., Bleil, U., Henrich, R., Kringstad, L., and Rolfsen, S., 1989. Oxygen and carbon isotope stratigraphy and magnetostratigraphy of the last $2.8 \mathrm{Ma}$ : paleoclimatic comparisons between the Norwegian Sea and the North Atlantic. In Eldholm, O., Thiede, J., Taylor, E., et al., Proc. ODP Sci. Results, 104: College Station, TX (Ocean Drilling Program), 255-269.

Johannessen, T., 1987. Resente planktoniske foraminiferer fra Norskehavet, Islandshavet og Nord-Atlanteren: taksonomi, fauna- 
fordeling og stabil-isotopsammensetning. Hovedoppgave i marin geologi ved Universitetet i Bergen [Cand. scient. thesis]. Univ. Bergen, Bergen, Norway.

Kennett, J. P., 1982. Marine Geology: Englewood Cliffs, NJ (Prentice Hall).

(Ed.), 1985. The Miocene Ocean: Paleoceanography and Biogeography. Mem. Geol. Soc. Am., 163.

Labeyrie, L., Pichon, J.-J., Labracherie, M., Ippolito, P., Duprat, J., and Duplessy, J.-C., 1986. Melting history of Antarctica during the past 60,000 years. Nature, 322:701-706.

Lutze, G. F., and Coulbourn, W., 1984. Recent benthic foraminifera from the continental margin of northwest Africa: community structure and distribution patterns. Mar. Micropaleontol., 8:361401.

Mackensen, A., Grobe, H., Kuhn, G., and Fütterer, D. K., 1990. Benthic foraminiferal assemblages from the eastern Weddell Sea between $68^{\circ}$ and $73^{\circ} \mathrm{S}$ : distribution, ecology and fossilization potential. Mar. Micropaleontol., 16:241-283.

Mackensen, A., Sejrup, H. P., and Jansen, E., 1985. The distribution of living and dead benthic foraminifera on the continental slope and rise off southwest Norway. Mar. Micropaleontol., 9:275-306.

Matthews, R. K., and Poore, R. Z., 1980. Tertiary $\delta^{18} \mathrm{O}$ record and glacio-eustatic sea-level fluctuations. Geology, 8:501-504.

Mercer, J. H., 1983. Cenozoic glaciations in the Southern Hemisphere. Annu. Rev. Earth Planet. Sci., 11:99-132.

Miller, K. G., and Fairbanks, R. G., 1985. Oligocene to Miocene carbon isotope cycles and abyssal circulation changes. In Sundquist, E. J., and Broecker, W. S. (Eds.), The Carbon Cycle and Atmospheric $\mathrm{CO}_{2}$ : Natural Variations Archean to Present. Am. Geophys. Union Geophys. Monogr., 32:469-486.

Miller, K. G., Fairbanks, R. G., and Mountain, G. S., 1987a. Tertiary oxygen isotope synthesis, sea-level history, and continental margin erosion. Paleoceanography, 2:1-19.

Miller, K. G., Fairbanks, R. G., and Thomas, E., 1987b. Benthic foraminiferal carbon isotopic records and the development of abyssal circulation in the eastern North Atlantic. In Ruddiman, W. F., Kidd, R. B., Thomas, E., et al., Init. Repts. DSDP, 94, Pt. 2: Washington (U.S. Govt. Printing Office), 981-996.

Miller, K. G., and Lohmann, G. P., 1982. Environmental distribution of Recent benthic foraminifera on the northeast United States continental slope. Geol. Soc. Am. Bull., 93:200-206.

Miller, K. G., Wright, J. D., and Fairbanks, R. G., 1991. Unlocking the icehouse. J. Geophys. Res., 96:6829-6848.

Plancke, J., 1977. Phytoplankton biomass and productivity in the subtropical convergence area and shelves of the western Indian subantarctic islands. In Llano, G. A. (Ed.), Adaptations Within Antarctic Ecosystems: Washington (Smithonian Inst.), 51-73.

Prentice, M. L., and Matthews, R. K., 1988. Cenozoic ice-volume history: development of a composite oxygen isotope record. Geology, 16:963-966.

Savin, S. M., and Douglas, R. G., 1973. Stable isotope and magnesium geochemistry of Recent planktonic foraminifera from the South Pacific. Geol. Soc. Am. Bull., 84:2317-2342.
Savin, S. M., Douglas, R. G., Keller, G., Killingley, J. S., Shaughnessy, L., Sommer, M. A., Vincent, E., and Woodruff, F., 1981. Miocene benthic foraminiferal isotope records: a synthesis. Mar. Micropaleontol., 6:423-450.

Savin, S. M., Douglas, R. G., and Stehli, F. G., 1975. Tertiary marine paleotemperatures. Geol. Soc. Am. Bull., 86:1499-1510.

Schlich, R., Wise, S. W., Jr., et al., 1989. Proc. ODP, Init. Repts., 120: College Station, TX (Ocean Drilling Program).

Shackleton, N. J., 1982. The deep-sea sediment record of climate variability. Prog. Oceanogr., 11:199-218.

Shackleton, N. J., and Kennett, J. P., 1975. Paleotemperature history of the Cenozoic and the initiation of Antarctic glaciation: oxygen and carbon isotope analyses in DSDP Sites 277, 279 and 281. In Kennett, J. P., Houtz, R. E., et al., Init. Repts. DSDP, 29: Washington (U.S. Govt. Printing Office), 743-755.

Thomas, E., 1985. Late Eocene to Recent deep-sea benthic foraminifers from the central equatorial Pacific Ocean. In Mayer, L., Theyer, F., Thomas, E., et al., Init. Repts. DSDP, 85: Washington (U.S. Govt. Printing Office), 655-694.

1990. Late Cretaceous through Neogene deep-sea benthic foraminifers (Maud Rise, Weddell Sea, Antarctica). In Barker, P. F., Kennett, J. P., et al., Proc. ODP, Sci. Results, 113: College Station, TX (Ocean Drilling Program), 571-594.

Thomas, E., and Vincent, E., 1987. Equatorial Pacific deep-sea benthic foraminifera: faunal changes before the middle Miocene polar cooling. Geology, 15:1035-1039.

Vincent, E., and Berger, W. H., 1985. Carbon dioxide and polar cooling in the Miocene: the Monterey Hypothesis. In Sundquist, E., and Broecker, W. S. (Eds.), The Carbon Cycle and Atmospheric $\mathrm{CO}_{2}$ : Natural Variations Archean to Present: Am. Geophys. Union, Geophys. Monogr. Ser., 32:455-468.

Whitworth, T., III, 1988. The Antarctic circumpolar current. Oceanus, 31:53-58.

Williams, D. F., Lerche, I., and Full, W. E., 1988. Isotope Chronostratigraphy: Theory and Methods: San Diego, CA (Academic Press).

Woodruff, F., and Savin, S., 1989. Miocene deep-water oceanography. Paleoceanography, 4:87-140.

in press. Mid-Miocene isotope stratigraphy in the deep-sea: high resolution correlations, paleoclimatic cycles, and sediment preservation. Paleoceanography.

Woodruff, F., Savin, S. M., and Douglas, R. G., 1981. Miocene stable isotope record: a detailed deep Pacific Ocean study and its paleoclimatic implications. Science, 212:665-668.

Date of initial receipt: 16 January 1990

Date of acceptance: 20 September 1990 Ms 120B-169 